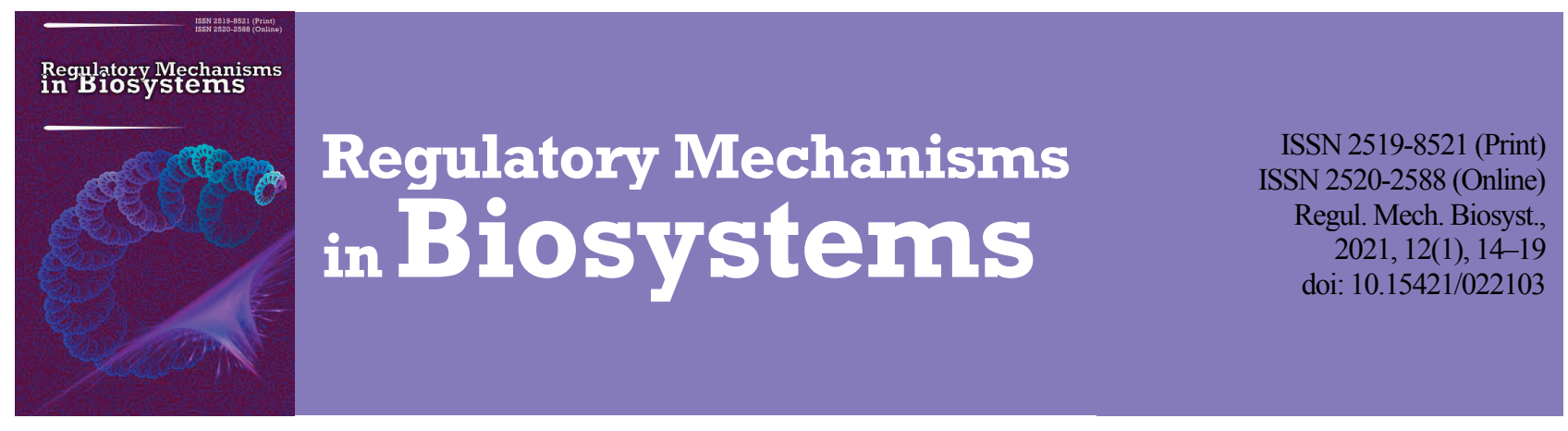

\title{
Quality variation of fruits of species of the genus Lycium in Ukraine: A comparative morphological analysis
}

\author{
M. Y. Zhurba*, S. V. Klymenko*, I. Szot** \\ *M. M. Gryshko National Botanical Garden of Ukraine of the National Academy of Sciences of Ukraine, Kyiv, Ukraine \\ **University of Life Sciences in Lublin, Lublin, Poland
}

Article info

Received 01.02.2021

Zhurba, M. Y., Klymenko, S. V., \& Szot, I. (2021). Quality variation of fruits of species of the genus Lycium in Ukraine: A comReceived in revised form 04.03.2021 Accepted 05.03.2021 parative morphological analysis. Regulatory Mechanisms in Biosystems, 12(1), 14-19. doi:10.15421/022103

M.M. Gryshko National Botanical Garden of Ukraine of the National Academy of Sciences of Ukraine Timiryazevska str., 1, Kyiv, 01014, Ukraine. Tel.: +38-067-367-65-42

E-mail:zhurbamikhail@gmail.com

University of Life Sciences

in Lublin, Faculty of Horticulture and Landscape Architecture, Institute of Horticultural Production Subdepartment of Pomology, Nursery and Enology, Akademicka st. 13, Lublin, 20-033, Poland. Tel.: +38-815-24-71.

E-mail:szoti@autograf.pl

Goji berries (Lycium L.) have been an important element of traditional Chinese medicine for centuries due to their healthpromoting properties and chemical composition, and they deserve the term "superfruit". The objective of this study was to evaluate the morphological parameters of Lycium (L. barbarum L., L. chinense Mill. and L. truncatum Y. C. Wang) fruits for 21 cultivars and varieties from the collections in the M. M. Gryshko National Botanical Garden of NAS of Ukraine (Kyiv). Cultivars and varieties differed by weight, shape, and size of fruits. Their morphometric parameters were the following: fruit weight from 0.44 ( $L$. truncatum cv. Princess Tao) to 1.08 (L. chinense cv. Tybet) g, fruit length from 10.41 (L. chinense cv. Delikat) to 22.84 (L. truncatum cv. Super Sweet) $\mathrm{mm}$, fruit diameter from 7.16 (L. truncatum cv. Princess Tao) to 13.48 (L. chinense cv. Delikat) mm, number of seeds in fruit from 1.0 to 49.0. The shape indexes of fruits were found ranging from 0.78 (L. chinense cv. Delikat) to 2.56 (L. truncatum cv. New Big). The analysis of coefficient of variation showed the difference of variability in morphometric characteristics between $\mathrm{Lycium}$ spp. cultivars and varieties. The most variable features are fruit weight (11.4-37.1\%) and number of seeds in fruits (9.7-60.8\%), which are important parameters for selection that indicates about potential success of selection. Using the cluster analysis with the Bray-Curtis similarity index allowed us to establish the relationships among the fruits Lycium spp. germplasm and arrange the cultivars and varieties into three relatively main clusters. Plants of the genus Lycium, due to the growing importance as functional food, require systematic research work. In cases of food use, large fruit size is important. In the results of our research on $L$. barbarum, $L$. chinense and L. truncatum, in terms of fruit sizes the following cultivars and varieties stand out : LB02, LC Amber Sweet and LT Super Sweet. The collected varieties can be the basis for obtaining new cultivars distinguished by the size of crops and their quality.

Keywords: goji berry; cultivars; varieties; fruits; seeds; morphometric parameters; cluster hierarchical analysis.

\section{Introduction}

The genus Lycium L. (Solanaceae Juss.) includes about 92(97) species, widespread in temperate and subtropical zones. Its shrubs or small trees are mostly found in arid or semi-arid, semisaline environments (Levin et al., 2011; Barboza et al., 2016). 35 species from all genus are used as food or medicine (Yao et al., 2018a).

But goji berries are the most used in the quality of 'superfood'. Under this name, the fruits of two species from east Asia: L. barbarum L. and L. chinense Mill. are consumed. They have been used in Chinese medicine for over 2000 years (Amagase \& Farnsworth, 2017; Yao et al., 2017). Lycii Fructus (fruits of Lycium) are listed into several pharmacopeias, including China, Europe and UK (Chang et al., 2015; Yao et al., 2017).

Goji berries have high anti-cancer (Wawruszak et al., 2016; Cumaoglu et al., 2018), anti-hyperglycemic (Potterat, 2010; Wojdyło et al., 2018), antioxidant (Protti et al., 2017; Ma et al., 2019), anti-inflammatory (Liu et al., 2015; Nardi et al., 2016; Wang et al., 2017), and anti-aging properties (Chang et al., 2015; Wojdyło et al., 2018). The fruits are characterized by a high amount of ascorbic acid (Niro et al., 2017), carotenoids (Chang et al., 2015), polysaccharides (Li et al., 2007; Wang et al., 2010), betaine (Xie et al., 2001; Lee et al., 2014) and taurine (Potterat, 2010).

In China, more than 150,000 ha are occupied by the goji crop, they are also grown in Europe and the USA (Yao et al., 2018). The fruits of goji berries are used in fresh and dried condition and juices, wine, preserves are made from them and also a substitute of tea is made from their leaves (Potterat et al., 2010; Yao et al., 2018). Not only do the fruits con- tain biologically active substances, but also other parts of the plants, especially leaves (Grygorieva et al., 2020; Szot et al., 2020). L. barbarum and L. chinense are the most common species in both hemispheres (GBIF.org, http://doi.org/10.15468/ dl.23c8y6, http://doi.org/10.15468/dl.at62jg). In Europe, including Ukraine, both species have naturalized and are neophytes, a component of the synantropic flora (Mosyakin et al., 1999; Pyšek et al., 2002).

The purpose of this study was to determine the variability of some morphological characteristics of fruits Lycium spp. The obtained results will help to select promising genotypes for further breeding work and to evaluate the prospects of promising use of selected samples.

\section{Materials and methods}

The plants were grown in M. M. Gryshko National Botanical Garden of NAS of Ukraine (Kyiv) from seeds or cuttings obtained from China, France, Slovak Republic and other Botanical Gardens of Ukraine. There 21 genotypes were investigated in an experimental study 2016-2019, including three species (Lycium barbarum, L. chinense, L. truncatum) and 10 cultivars and 11 varieties (LB01-LB03, LC01-LC05, LT01). Samples were marked as LB (L. barbarum), LC (L. chinense), LT (L. truncatum).

30 fruits from each genotype were used immediately after harvest for phenotypic measurements such as fruit weight, $(\mathrm{FW})$, in $\mathrm{g}$, fruit length (FL), in mm, fruit diameter (FD), in mm. Fruit mass was measured by using a digital balance with a sensitivity of $0.01 \mathrm{~g}(\mathrm{PS} 6000 / \mathrm{C} / 1)$. Linear dimensions of fruits as length and diameter were measured by using a 
digital calliper gauge with a sensitivity of $0.01 \mathrm{~mm}$, then the shape index was calculated by using length/width ratio. Basic statistical analyses - the minimal and maximal values of the traits, arithmetic means, and coefficient of variation $(\mathrm{V}, \%)$ were performed using PAST 2.17 (Norway, 2001). Results of the morphometric analysis were determined by mean \pm standard deviation (SD) and statistical significance was estimated. Hierarchical cluster analyses of similarity between phenotypes were computed by the Bray-Curtis similarity index and were performed using PAST 2.17.

\section{Results}

The differences in weight, shape, size, colour of fruits from the collection of the M. M. Gryshko National Botanical Garden are shown in Figure 1. The minimum and maximum values for the weight, length, diameter, shape index of fruit, and number of seeds in the twenty-one Lycium spp. are shown in Table 1.

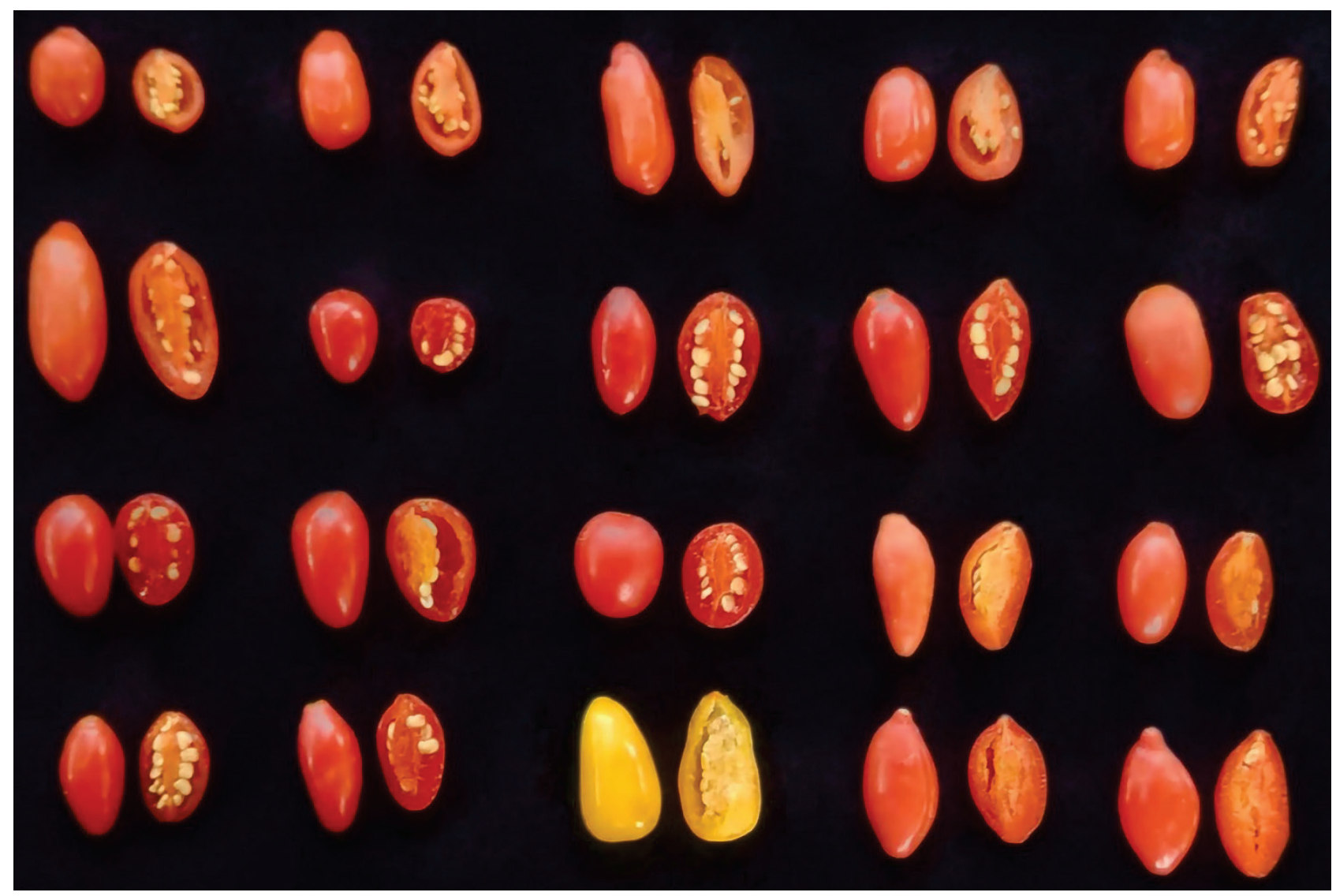

Fig. 1. Variability of fruits of Lycium spp.

Table 1

Variation limits of fruits of species of the genus Lycium cultivars and varieties

\begin{tabular}{|c|c|c|c|c|c|c|c|c|c|c|}
\hline \multirow{2}{*}{$\begin{array}{c}\text { Species, } \\
\text { cultivars, varieties }\end{array}$} & \multicolumn{2}{|c|}{ Fruit weight, $\mathrm{g}$} & \multicolumn{2}{|c|}{ Fruit length, mm } & \multicolumn{2}{|c|}{ Fruit diameter, $\mathrm{mm}$} & \multicolumn{2}{|c|}{ Shape index } & \multicolumn{2}{|c|}{ Number of seeds in fruit } \\
\hline & $\min$ & $\max$ & $\min$ & $\max$ & $\min$ & $\max$ & $\min$ & $\max$ & $\min$ & $\max$ \\
\hline \multicolumn{11}{|c|}{ Lycium barbarum } \\
\hline LB01 & 0.25 & 1.24 & 14.00 & 23.00 & 5.00 & 10.00 & 1.56 & 3.20 & 5 & 29 \\
\hline LB02 & 0.54 & 1.70 & 15.71 & 27.84 & 7.77 & 11.40 & 1.85 & 2.74 & 5 & 35 \\
\hline LB03 & 0.41 & 1.30 & 13.74 & 22.65 & 7.09 & 10.63 & 1.69 & 2.61 & 5 & 29 \\
\hline LB Wild & 0.10 & 1.07 & 6.11 & 22.25 & 3.51 & 11.60 & 1.00 & 2.58 & 1 & 16 \\
\hline \multicolumn{11}{|c|}{ Lycium chinense } \\
\hline LC01 & 0.68 & 1.13 & 15.70 & 19.07 & 8.22 & 10.49 & 1.57 & 2.21 & 12 & 32 \\
\hline $\mathrm{LCO} 2$ & 0.31 & 0.67 & 11.17 & 14.43 & 6.23 & 9.11 & 1.37 & 1.93 & 10 & 26 \\
\hline $\mathrm{LC} 03$ & 0.56 & 1.25 & 15.00 & 20.00 & 7.00 & 10.00 & 1.78 & 2.57 & 15 & 31 \\
\hline $\mathrm{LC} 04$ & 0.68 & 1.52 & 9.78 & 21.09 & 8.07 & 11.80 & 1.03 & 2.27 & 10 & 34 \\
\hline LC05 & 0.54 & 1.47 & 15.00 & 19.00 & 8.00 & 11.00 & 1.60 & 2.25 & 10 & 30 \\
\hline LC Amber Sweet & 0.51 & 1.71 & 13.04 & 21.60 & 7.09 & 11.30 & 1.38 & 2.24 & 6 & 17 \\
\hline LC Big Lifeberry & 0.49 & 1.13 & 16.00 & 20.00 & 8.00 & 10.50 & 1.70 & 2.38 & 13 & 35 \\
\hline LC Delikat & 0.61 & 1.24 & 9.00 & 12.00 & 11.00 & 16.00 & 0.67 & 0.92 & 13 & 30 \\
\hline LCQ1 & 0.43 & 1.07 & 15.00 & 22.00 & 7.00 & 10.00 & 1.67 & 2.79 & 5 & 23 \\
\hline LC Sweet Lifeberry & 0.54 & 0.85 & 13.99 & 19.34 & 7.06 & 9.82 & 1.69 & 2.28 & 17 & 28 \\
\hline LC Tybet & 0.65 & 1.52 & 13.00 & 19.00 & 8.00 & 11.50 & 1.27 & 1.89 & 8 & 38 \\
\hline \multicolumn{11}{|c|}{ Lycium truncatum } \\
\hline LT01 & 0.27 & 0.93 & 10.88 & 17.30 & 6.13 & 11.06 & 1.27 & 1.85 & 13 & 33 \\
\hline LT Super Sweet & 0.48 & 1.68 & 15.69 & 28.27 & 6.40 & 11.43 & 2.08 & 3.18 & 9 & 37 \\
\hline LT Korean Big & 0.23 & 0.86 & 9.66 & 20.48 & 6.04 & 9.95 & 1.34 & 2.50 & 8 & 42 \\
\hline LT N1 Lifeberry & 0.43 & 0.94 & 14.18 & 22.24 & 6.48 & 9.68 & 1.69 & 2.69 & 11 & 49 \\
\hline LT New Big & 0.55 & 1.29 & 18.47 & 25.89 & 6.93 & 9.72 & 2.17 & 3.09 & 18 & 36 \\
\hline LT Princess Tao & 0.31 & 0.61 & 12.09 & 16.92 & 5.66 & 2.37 & 1.48 & 2.51 & 5 & 31 \\
\hline
\end{tabular}

Note: $\min$ - minimal value; $\max$ - maximal value. 
Variation limits for fruit length varied between $6.11 \mathrm{~mm}$ for cv. Wild (L. barbarum) to $28.27 \mathrm{~mm}$ for cv. Super Sweet (L. truncatum, Table 1). The value of diameter varied within the interval from $3.51 \mathrm{~mm}$ (L. barbarum cv. Wild) to $11.80 \mathrm{~mm}$ (L. chinense var. LC 04). Fruit weight, economically the most important characteristic, ranged of $0.10 \mathrm{~g}$ ( $L$. barbarum cv. Wild) to $1.71 \mathrm{~g}$ (L. chinense cv. Amber Sweet). In this experiment, the average weight of a single fruit exceeded $1 \mathrm{~g}$ in the case of: LB 02, LC 04, LC 05, LC Amber Sweet, LC Tybet and LT Super Sweet. The average weight of the fruits was determined in the range of 0.44 (L. truncatum cv. Princess Tao) to $1.08 \mathrm{~g}$ (L. chinense cv. Tybet), fruits length from 10.41 (L. chinense cv. Delikat) to $22.84 \mathrm{~mm}$ (L. truncatum cv. Super Sweet), fruits' diameter from 7.16 (L. truncatum cv. Princess Tao) to $13.48 \mathrm{~mm}$ (L. chinense cv. Delikat, Fig. 2, 3). The shape index (Fig. 4) of fruits ranged from 0.78 (L. chinense cv. Delikat) to 2.56 (L. truncatum cv. New Big).

Number of seeds in fruit was identified in the range from 1 (LB_Wild) to 49 (LT_N1 Lifeberry). Lycium barbarum fruit contains 135 seeds, L. chinense - 5-38, L. truncatum - 5-49 seeds. These results indicate the great variability of this trait. The analysis of coefficient of variation showed the significant variability of morphological signs between Lycium spp. cultivars and varieties. The variation coefficients (\%) ranged between 11.41 (L. chinense cv. Q1) and 37.12 (L. chinense cv. Delikat) for fruit weight, between $4.31 \mathrm{~mm}$ (L. chinense cv. Q1) and 20.40 (L. chinense cv. Delikat) for fruit length, between 5.05 (L. chinense var. LC_05) and 14.09 (L. chinense cv. Delikat) for fruit diameter, between 4.51 (L. truncatum cv. N1 Lifeberry) and 14.44 (L. chinense cv. Delikat) for the shape index, and between 9.73 (L. truncatum cv. N1 Lifeberry) and 60.78 ( L. chinense cv. Delikat) for number of seeds in fruits. Data showed that the most variable important selection signs are the fruit weight and number of seeds in fruits. These results indicate the promise of breeding in this way of investigation.

The above data shown in Figures 2-5 are confirmed by cluster analysis. In clustering, all studied parameters for 21 cultivars and varieties of the Lycium spp. were used, and the resulting clusters are shown in Figure 6. On the basis of data presented in Figure 6 it could be said that cluster analysis separates Lycium spp. selections into three main Clusters.

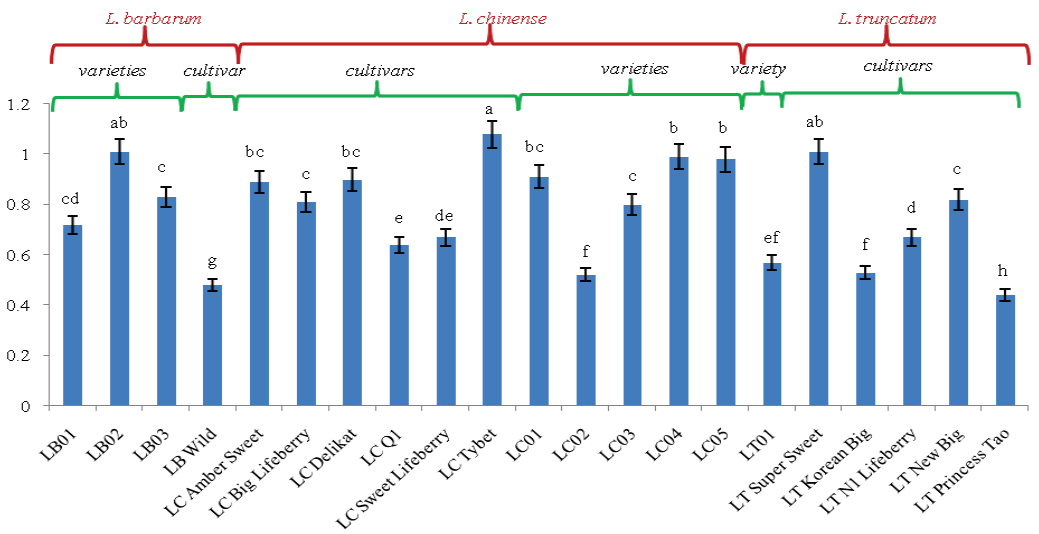

Fig. 2. Fruits weight of Lycium spp. cultivars and varieties: means in columns followed by different letters are different by $\mathrm{P}<0.05$

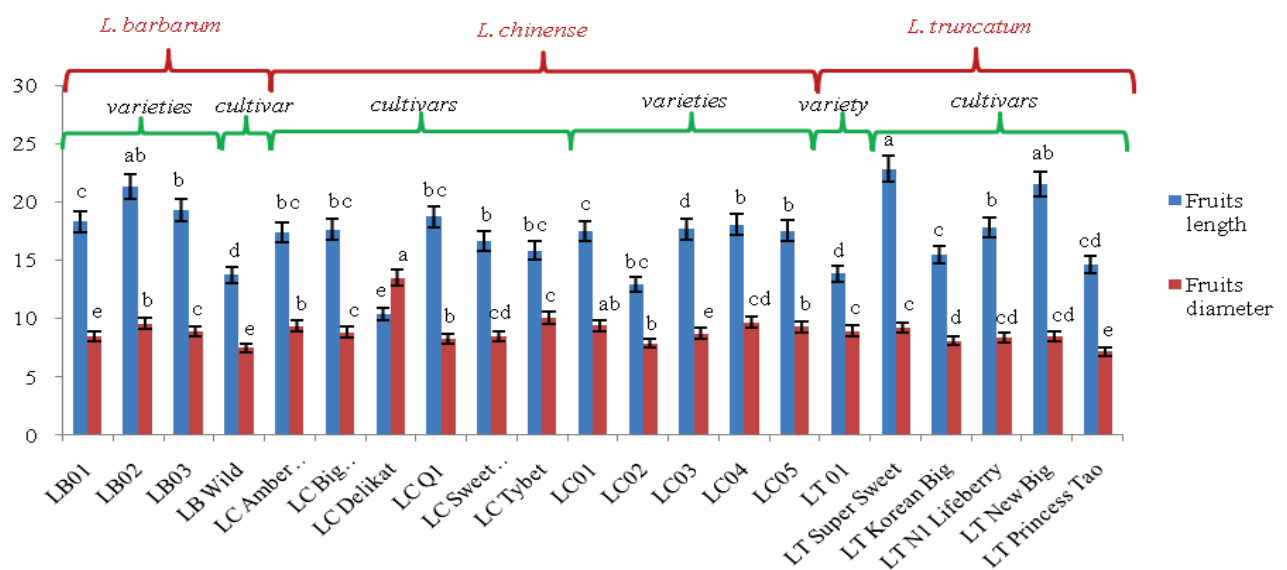

Fig. 3. Fruits length and diameter of Lycium spp. cultivars and varieties: see Fig. 2

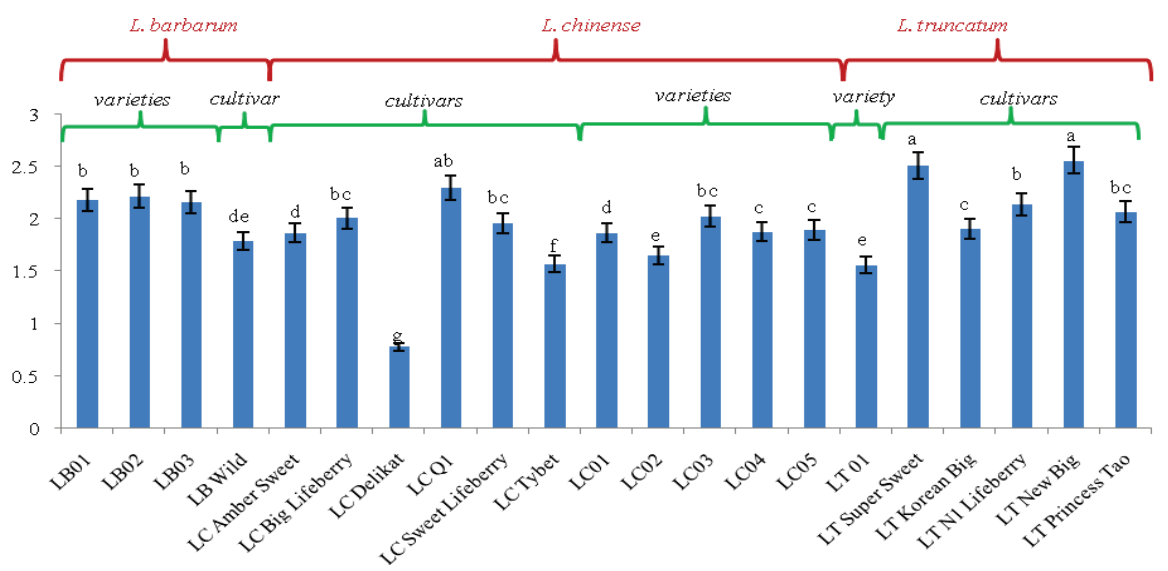

Fig. 4. Comparison of the Lycium spp. cultivars and varieties in the shape index of fruits: see Fig. 2 


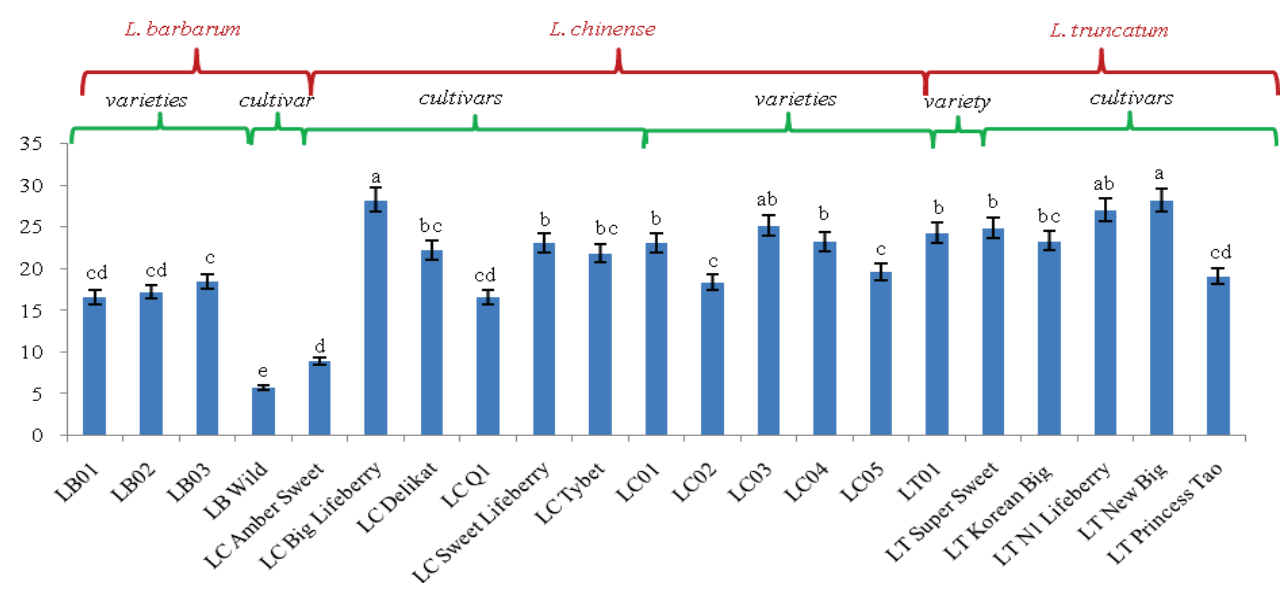

Fig. 5. Number of seeds in fruit of Lycium spp. cultivars and varieties: see Fig. 2

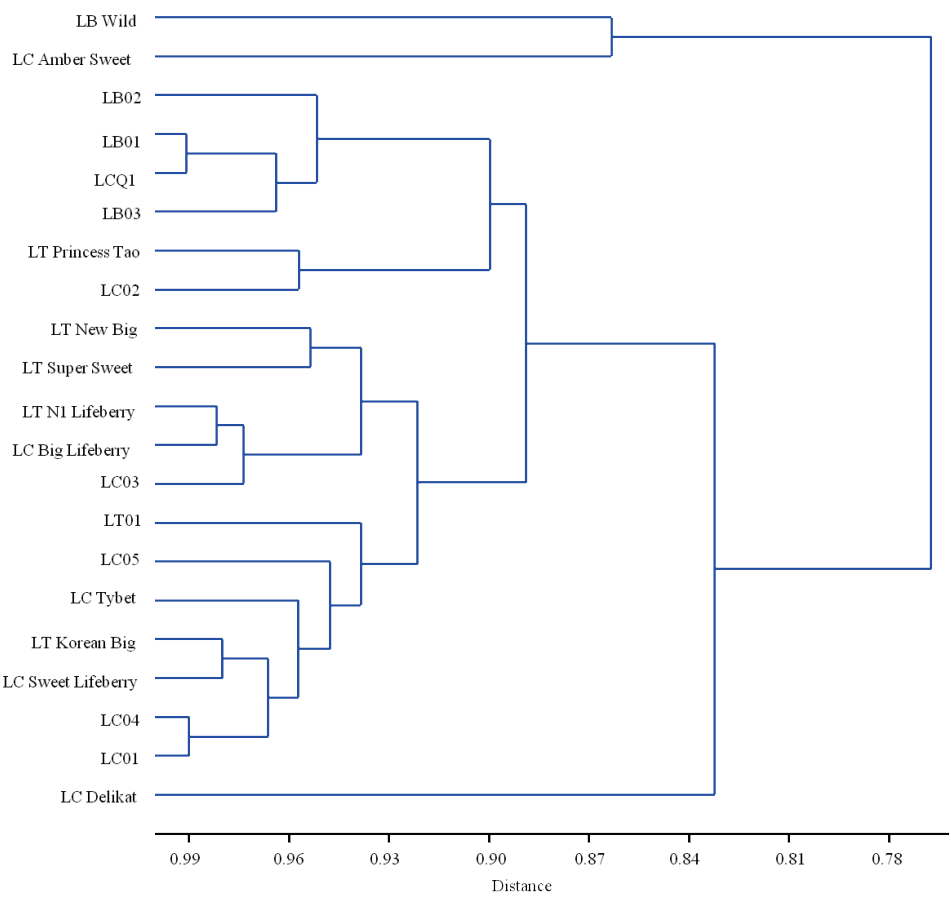

Fig. 6. Cluster dendrogram analyzed on four morphometric parameters of fruits of Lycium spp. 21 cultivars and varieties

The Cluster I contained two cultivars Wild (L. barbarum) and Amber Sweet ( $L$. chinense) only, and these two cultivars differed by the least number of seeds in the fruit. The largest number of samples (18 cultivars and varieties) was included in Cluster II. The Cluster III consisted of the cultivar Delikat (L. chinense) which is found to be furthest from all other genotypes Cluster I, II, and differs from other ones by the smallest shape index and fruits length and the largest diameter of the fruits.

\section{Discussion}

In Ukraine, goji has not been investigated or grown on an industrial commercial scale. Since 2016, the Department of Fruit Plants Acclimatisation (M. M. Gryshko National Botanical Garden) has been working on creating a Lycium spp. collection. Our collection includes 45 genotypes from seeds or cuttings obtained from China, France, Slovak Republic and other Botanical Gardens of Ukraine. In the selection process 26 promising genotypes of Lycium spp were involved, of which 9 candidates were selected for cultivars. Among the studied L. barbarum plants a group was identified that differed in features of the structure of flowers and the nature of pubescence of the corolla and petals. According to the description in Flora of China, the plants correspond to the species L. truncatum Y.C. Wang. Therefore, such cultivars as Ningqi 1 (N1 Lifeberry), Super Sweet, Korean Big, New Big and Prncess Tao have been considered within this species.
Currently, only in China are breeding programs focused mainly on species: $L$. barbarum, $L$. chinense and $L$. ruthenicum. The first selection work started in China at 1960-1970s at the Ningxia Research Center of Wolfberry Engineering Technology (China), which was renamed as National Wolfberry Engineering Research Center in 2011 (Chen et al., 2018). The result of their work is only a few established and used cultivars: Damaye and Ningqi 1 (in Europe known as N1 Lifeberry). As noted by the authorization, breeding work was conducted with $L$. barbarum. In Europe, the largest plantations are laid in Germany, Serbia, Macedonia, Greece, Bulgaria, Spain and Portugal. The cultivation of goji berries in Poland is still developing. There are companies supporting the establishment of plantations. Several companies have also been launched to deal with the purchase and processing of fruit. In Poland, Chinese wolfberry $(L$. barbarum) selection is introduced, mostly based on seeds of this species imported from Tibet and China. Among several types the best rated is NQ 1 and it has been incorporated into nursery production. Bulgarian varieties are also available: JB1, JB2, JBX and JB4. Planting by sowing seeds is also promoted (Marosz, 2017).

Azim et al. (2018) pointed that fruit diameter of barberry is response to different areas revealed a wide range of differences with each other. Mean values of fruit diameter ranged from 6-9 $\mathrm{mm}$ in various ecotypes. Kazbekovna et al. (2018) comparing morphological features of $L$. barbarum fruits from the North Caucasus stated that length of fruits ranged from 8 to $18 \mathrm{~mm}$ and their diameter from 5 to $10 \mathrm{~mm}$. Commercial goji are 
categorized into six grades depending on the number of fruits per $50 \mathrm{~g}$. In the best grade there are 180-200 fruits per $50 \mathrm{~g}$ and in the lowest grade 980 fruits (Yao et al., 2018). Chen et al. (2018) stated that the weight of 1000 fruit of valuable varieties such as Damaya and Nangqi was 450-510 and $586 \mathrm{~g}$, respectively. Azim et al. (2018) stated that 100 fruit weight was highly significantly positively correlated with fruit diameter and was non significantly positively correlated with plant height, main stem diameter, number of thorns and plant canopy.

Our results have shown that investigated parameters values are similar within those obtained by Wang et al. (2011), Qin et al. (2012a, b), Dai et al. (2015), Yang et al. (2015), and Zhurba (2019) (Table 2).

\section{Table 2}

Variability of some morphometric characteristics of Lycium spp. fruits according to the authors from different countries

\begin{tabular}{llccc}
\hline \multicolumn{1}{c}{ Autors } & \multicolumn{1}{c}{ Species, cultivars } & $\begin{array}{c}\text { Fruit } \\
\text { weight, g }\end{array}$ & $\begin{array}{c}\text { Fruit } \\
\text { length, mm }\end{array}$ & $\begin{array}{c}\text { Fruit dia- } \\
\text { meter, mm }\end{array}$ \\
\hline Wang et al., 2011 & Lycium (cv. Ningqi 6) & 1.29 & 22.73 & 9.29 \\
Qin et al., 2012a & Lycium (cv. Ningqi 7) & $-^{*}$ & 22.0 & 1.18 \\
Qin et al., 2012b & Lycium (cv. Ningqi 5) & 1.10 & 25.40 & 17.40 \\
Dai et al., 2015 & $\begin{array}{l}\text { L. barbarum } \\
\text { (cv.Ningnongqi 9) }\end{array}$ & 1.06 & $-*$ & $-^{*}$ \\
Yang et al., 2015 & Lycium (cv. Zhongke & & & \\
Zhurba, 2019 & Lüchuan 1) & $-*$ & 14.20 & 13.60 \\
According & L. chinense & 0.81 & 16.13 & 9.35 \\
to our data & L. barbarum & 0.74 & 17.83 & 8.42 \\
& L. chinense & 0.84 & 16.40 & 9.41 \\
& L. truncatum & 0.67 & 17.69 & 8.36 \\
\hline
\end{tabular}

Note: *-no data available.

Lin (2013) and Qi et al. (2016) report that fruit traits of goji are affected by temperature, humidity, duration of sunshine and altitude. Also, fruit morphology may differ even within the same climatic region (Lei et al., 2013). Yao et al. (2018) report that goji from monsoon, plateau and arid regions differ according to their fruit morphology, whereas semi-arid goji cannot be separated from those of other regions. $L$. chinense fruits, which are exclusively cultivated in Hebei (monsoon), are significantly lighter, smaller and brighter in colour, while the heaviest and largest fruits (L. barbarum) stem from the plateau.

The shape of each object can be characterized by the shape index, i.e. the length to width ratio. In the study by Yao et al. (2018) goji from the plateau regions has the largest, while those from the arid regions shows the smallest length/width ratio. Goji from the plateau appears to be elongated oval or lancelolate, while those from from other regions are of shorter oval shape.

Cluster analysis has been used for evaluation of genetic diversity in many crops such as Cornus mas L. (Jaćimović et al., 2015), Helianthus anmuus L. (Ruzdik et al., 2015), Aronia mitschurinii A. K. Skvortsov \& Maitul. (Vinogradova et al., 2017), Ziziphus jujuba Mill. (Ivanišová et al., 2017), Elaeagnus multiflora Thunb. (Grygorieva et al., 2018a), Mespilus germanica L. (Grygorieva et al., 2018b), and Sambucus nigra L. (Horčinová Sedláčková et al., 2019). This analysis demonstrates the integrated character of the variability of the studied species, cultivars and indicates possible ways to artificially improve the genetic material. The data obtained allow us to estimate the state of the collection in M. M. Gryshko National Botanical Garden in Kyiv (Ukraine) as quite high.

\section{Conclusions}

Plants of the genus Lycium, due to their growing importance as functional food, require systematic research work. In the case of food use large fruit size is important. In the results of our research on $L$. barbarum, $L$. chinense and L. truncatum, in terms of fruit sizes for the following genotype and varieties stand out : LB02, LC Amber Sweet and LT Super Sweet. The collected varieties and genotypes can be the basis for obtaining new varieties distinguished by the size of crops and their quality.

The publication was prepared with the active participation of researchers in International Network AgroBioNet within the project ITMS 25110320104 "Innovation of test methods and procedures for the detection of sources of bioactive substances for the improvement of health and quality of life". The authors is grateful to the Visegrad Fund (52011113).

\section{References}

Amagase, H., \& Farnsworth, N. R. (2011). A review of botanical characteristics, phytochemistry, clinical relevance in efficacy and safety of Lycium barbarum fruit (Goji). Food Research International, 44(7), 1702-1717.

Azim, R., Ilyas, M., Awan, S. I., Tariq, H., \& Iqbal, N. (2018). Assesment of morphological and biochemical diversity of berries Lycium in the three districts of Azad Jammu and Kashmir. International Journal of Bioscences, 12(6), 37-47.

Barboza, G. E., Hunziker, A. T., Bernardello, G., Cocucci, A. A., Carrizo Garcia, C., Fuentes, V., Dillon, M. O., Bittrich, V., Cosa, M. T., Subils, R., Romanutti, A., Arroyo, S., \& Anton, A. (2016). Solanaceae. In: Kadereit, J. W., \& Bittrich, V. (Eds.). The families and genera of vascular plants. Vol. 14. Springer, New Delhi. Pp. 295-357.

Chang, R. C.-C., \& So, K.-F. (2015). Lycium barbarum and human health. Springer, Netherlands.

Chen, J., Chao, C. T., \& Wei, X. (2018). Gojiberry breeding: Current status and future prospects. In: Breeding and health benefits of fruit and nut crops. InTech, Delhi. Pp. 3-20.

Cumaoglu, A., Bekci, H., Ozturk, E., Yerer, M. B., Baldemir, A., \& Bishayee, A. (2018). Goji berry fruit extracts suppress proliferation of triple-negative breast cancer cells by inhibiting EGFR-Mediated ERK/MAPK and PI3K/Akt signaling pathways. Natural Product Communications, 13(6), 701-706.

Dai, G., Cao, Y., Lei, Z., Jiao, E., Qin, K., \& Zhou, X. (2015). A new wolfberry cultivar'Ningqi 5'. Acta Horticulturae Sinica, 39(10), 2099-2100.

Grygorieva, O., Klymenko, S., Ilinska, A., \& Brindza, J. (2018a). Variation of fruits morphometric parameters of Elaeagnus multiflora Thunb. germplasm collection. Potravinarstvo Slovak Journal of Food Sciences, 12(1), 527-532.

Grygorieva, O., Klymenko, S., Vinogradova, Y., Motyleva, S., Gurnenko, I., Piórecki, N., \& Brindza, J. (2018). Study of morphological characteristics of pollen grains of Aronia mitschurinii A. K. Skvortsov \& Maitul. Agrobiodiversity for Improving Nutrition, Health and Life Quality, 2, 49-56.

Grygorieva, O., Klymenko, S., Vinogradova, Y., Vergun, O., \& Brindza, J. (2018b) Variation in morphometric traits of fruits of Mespilus germanica L. Potravinarstvo Slovak Journal of Food Sciences, 12(1), 782-788.

Grygorieva, O., Vergun, O., Klymenko, S., Zhurba, M., Horčinová Sedláčková, V., Ivanišová, E., \& Brindza, J. (2020). Estimation of phenolic compounds content and antioxidant activity of leaves extracts of some selected non-traditional plants. Potravinarstvo Slovak Journal of Food Sciences, 14, 501-509.

Horčinová Sedláčková, V., Grygorieva, O., Vergun, O. M., Vinogradova, J. K., \& Brindza, J. (2019). Comparison of selected characteristics of cultivars and wildgrowing genotypes of Sambucus nigra in Slovakia. Biosystems Diversity, 27, 56-61.

Ivanišová, E., Grygorieva, O., Abrahamová, V., Schubertova, Z., Terentjeva, M., \& Brindza, J. (2017). Characterization of morphological parameters and biological activity of jujube fruit (Ziziphus jujuba Mill.). Journal of Berry Research, 7, $249-260$.

Jaćimović, V., Božović, D., Ercisli, S., Ognjanov, V., \& Bosančić, B. (2015). Some Fruit characteristics of selected comelian cherries (Cornus mas L.) from Montenegro. Erwerbs-Obstbau, 57, 119-124.

Kazbekovna, S. F., Arsenovna, S. M., \& Nikolaevich, D. O. (2018). Comparative micromorphological investigations of red goji berries (Lycium barbarum L.) and black godji berries (Lycium ruthenicum Murr.). Pharmacognosy Journal, 10(5), 911-915.

Lee, H. W., Kim, Y. H., Kim, Y. H., Lee, G. H., \& Lee, M. Y. (2014). Discrimination of Lycium chinense and Lycium barbarum by taste pattern and betaine analysis. International Journal of Clinical and Experimental Medicine, 7(8), 2053-2059.

Lei, J., Liu, D., \& Guo, J. (2013). Quality differences of Lycium barbarum L. dried fruit in different producing areas. Xiandai Shipin Keji, 29, 494 497.

Levin, R. A., Bemardello, G., Whiting, C., \& Miller, J. S. (2011). A new generic circumscription in tribe Lycieae (Solanaceae). Taxon, 60(3), 681-690.

Li, X. M., Li, X. L., \& Zhou, A. G. (2007). Evaluation of antioxidant activity of the polysaccharides extracted from Lycium barbarum fruits in vitro. European Polymer Journal, 43(2), $488-497$.

Lin, L. (2013). A comparative study on the quality of Lycium barbarum fruit from different producing areas and screening of fine strains. Gansu Agricultural University, Gansu.

Liu, Y., Lv, J., Yang, B., Liu, F., Tian, Z., Cai, Y., Yang, D., Ouyang, J., Sun, F., Shi, Y., \& Xia, P. (2015). Lycium barbarum polysaccharide attenuates type II collagen-induced arthritis in mice. International Journal of Biological Macromolecules, 78, 318-323.

Ma, Z. F., Zhang, H., Teh, S. S., Wang, C. W., Zhang, Y., Hayford, F., Wang, L., Ma, T., Dong, Z., Zhang, Y., \& Zhu, Y. (2019). Goji berries as a potential natu- 
ral antioxidant medicine: An insight into their molecular mechanisms of action Oxidative Medicine and Cellular Longevity, 2019, 1-9.

Marosz, A. (2017). Fruits of goji berry (Lycium barbarum and Lycium chinense)new possibility for horticulture or risk for consumers? Annales Horticulturae, 27(1), 19-30

Mosyakin, S. L., \& Fedoronchuk, M. M. (1999). Vascular plants of Ukraine: A nomenclatural checklist. M. G. Kholodny Institute of Botany, Kiev.

Nardi, G. M., De Farias Januário, A. G., Freire, C. G., Megiolaro, F., Schneider, K. Perazzoli, M. R. A., Nascimento, S. R. D., Gon, A. C., Mariano, L. N. B., Wagner, G., Niero, R., Locatelli, C., \& Locatelli, C. (2016). Anti-inflammatory activity of berry fruits in mice model of inflammation is based on oxidative stress modulation. Pharmacognosy Research, 8, 42-49.

Niro, S., Fratianni, A., Panfili, G., Falasca, L., Cinquanta, L., \& Alam, M. R. (2017). Nutritional evaluation of fresh and dried goji berries cultivated in Italy. Italian Journal of Food Science, 29(3), 398-408.

Potterat, O. (2010). Goji (Lycium barbarum and L. chinense): Phytochemistry, pharmacology and safety in the perspective of traditional uses and recent popularity. Planta Medica, 76(1), 7-19.

Protti, M., Gualandi, I., Mandrioli, R., Zappoli, S., Tonelli, D., \& Mercolini, L. (2017). Analytical profiling of selected antioxidants and total antioxidant capacity of goji (Lycium spp.) berries. Journal of Pharmaceutical and Biomedical Analysis, 143, 252-260.

Pyšek, P., Sádlo, J., \& Mandák, B. (2002). Catalogue of alien plants of the Czech Republic. Preslia, 74, 97-186.

Qi, G., Su, X., Zheng, G., Yang, J., Bao, H., \& Wang, J. (2016). Effect of meteorological factor on fruit growth and accumulation of polysaccharides in Lycium barbarum. Chinese Bullerin of Botany, 51, 311-321.

Qian, D., Yang, J., Kang, L., Ji, R., \& Huang, L. (2017). Variation of sweet chemicals in different ripening stages of wolfberry fruits. Chinese Herbal Medicines, 9(4), 329-334.

Qin, K., Dai, G., Cao, Y., Jiao, E., Tang, H., Yan, Y., He, J., \& Li, R. (2012a). A new wolfberry cultivar 'Ningqi 7'. Acta Horticulturae Sinica, 39(11), 2331-2332.

Qin, K., Dai, G., Liu, Y., Tang, H., Jiao, E., Li, R., He, J., \& Yan, Y. (2012b). A new wolfberry cultivar 'Ningqi 5'. Acta Horticulturae Sinica, 39(10), 2099-2100.

Ruzdik, N. M., Karov, I., Mitrev, S., Gorgieva, B., Kovacevik, B., \& Kostadinovska, E. (2015). Evaluation of sunflower (Helianthus annums L.) varieties using multivariate statistical analysis. Helia, 38(63), 1-12.
Szot, I., Zhurba, M., \& Klymenko, S. (2020). Pro-health and functional properties of goji berry (Lycium spp.). Agrobiodiversity for Improving Nutrition, Health and Life Quality, 4, 134-145.

Vinogradova, Y., Grygorieva, O., Vergun, O., \& Brindza, J. (2017). Morphological characteristics for fruits of Aronia mitschurinii A. K. Skvortsov \& Maitul. Potravinarstvo Slovak Journal of Food Sciences, 11(1), 754-760.

Wang, C. C., Chang, S. C., Inbaraj, B. S., \& Chen, B. H. (2010). Isolation of carotenoids, flavonoids and polysaccharides from Lycium barbarum L. and evaluation of antioxidant activity. Food Chemistry, 120(1), 184-192.

Wang, S., Suh, J. H., Zheng, X., Wang, Y., \& Ho, C. T. (2017). Identification and quantification of potential anti-inflammatory hydroxycinnamic acid amides from wolfberry. Journal of Agricultural and Food Chemistry, 65(2), 364-372.

Wang, Y., Wang, J., \& Chang, H. (2011). A new table wolfberry cultivar 'Ningqi 6'. Acta Horticulturae Sinica, 38(5), 1015-1016.

Wawruszak, A., Czerwonka, A., Okła, K., \& Rzeski, W. (2016). Anticancer effect of ethanol Lycium barbarum (Goji berry) extract on human breast cancer T47D cell line. Natural Product Research, 30(17), 1993-1996.

Wojdyło, A., Nowicka, P., \& Bąbelewski, P. (2018). Phenolic and carotenoid profile of new goji cultivars and their anti-hyperglycemic, anti-aging and antioxidant properties. Joumal of Functional Foods, 48, 632-642.

Xie, C., Xu, L. Z., Li, X. M., Li, K. M., Zhao, B. H., \& Yang, S. L. (2001). Studies on chemical constituents in fruit of Lycium barbarum L. China Journal of Chinese Materia Medica, 26(5), 323-324.

Yang, T., Dong, J., Yue, J., \& Wang, Y. (2015). A new wolfberry cultivar 'Zhongke Luchuan 1'. Acta Horticulturae Sinica, 42(12), 2557-2558.

Yao, R., Heinrich, M., \& Weckerle, C. S. (2018a). The genus Lycium as food and medicine: A botanical, ethnobotanical and historical review. Journal of Ethnopharmacology, 212, 50-66.

Yao, R., Heinrich, M., Zou, Y., Reich, E., Zhang, X., Chen, Y., \& Weckerle, C. S. (2018b). Quality variation of goji (fruits of Lycium spp.) in China: A comparative morphological and metabolomic analysis. Frontiers in Pharmacology, 9, 1-12.

Zhurba, M. (2019). Morphomethric parameters of genotypes of Lycium chinense Mill. in collection of M. M. Gryshko National Botanical Garden of NAS of Ukraine. In: 4th International Scientific Conference Agrobiodiversity for Improve the Nutrition, Health and Quality of Human and Bees Life. Nitra. P. 155. 